FIEF Working Paper Series

No. 146

September 291998

\title{
The Growth and Welfare Effects of International Mass Migration*
}

\author{
by \\ Per Lundborg \\ The Trade Union Institute for Economic and Social Research, \\ Wallingatan 38, \\ S-111 24 Stockholm, Sweden \\ and \\ Paul S. Segerstrom \\ Department of Economics, Michigan State University, \\ East Lansing, MI 48824, USA
}

\begin{abstract}
We analyse the effects of immigration quotas on growth and discounted welfare in a North-South version of the quality ladders growth model. Immigration quotas in the North increase the growth rate of utility for all consumers. However, they lower the static utility level and discounted welfare of Northern workers. Also the discounted welfare of asset owners drops. Hence, unlike in the static migration model where the representative agent in the host country benefits from immigration, in our dynamic migration model, the representative agent loses despite a positive growth effect of immigration. In general, the winners of a liberal immigration policy in the North are the immigrants and the remaining workers in the South.

*This project has been financially supported by a grant from HSFR, (the Swedish Council for Research in Humanities and Social Sciences).
\end{abstract}

Keywords: Migration; growth; welfare JEL Codes: J61; O31 


\section{Introduction}

Many countries today face a situation of potential mass immigration. There are strong incentives for workers to migrate from low-wage, densely populated countries in Asia and Latin America to the United States and Canada. European countries experience a similar situation of potential mass immigration with respect to workers from North African countries. Also, the fact that the former communist countries in Eastern Europe and in Russia no longer prevent their workers from emigrating means that the European Union could increase its labor force substantially by allowing for large scale immigration from the East.

Indeed, the eastward enlargement which now is on the Union's agenda implies that many East European countries will be encompassed by the Union's free labor market after they have become members. ${ }^{1} \quad$ Three facts suggest that such a labor market integration could give rise to potential mass immigration into the EU. First, real wage differences between most of the present EU members and the candidate countries are huge. For example, a typical Polish worker who migrates to work in Germany but spends his income in Poland can raise his real wage by a factor of ten. ${ }^{2}$ Though growth rates are higher in the Eastern European countries than in the present EU, large real wage differences are likely to prevail for many years. Secondly, the labor force in the poor candidate countries is large, approximately 50 million people, which also suggests large potential migration flows. Finally, the geographical vicinity implies small moving costs associated with migration. ${ }^{3}$

In this paper we analyze the growth and welfare effects of large immigration quotas and long run integration that could imply mass immigration. Quotas have been a major policy tool in the rich countries, implemented already by Great Britain in 1905

${ }^{1}$ The countries that have applied for full membership are Hungary, Poland, the Czech Republic, Slovakia, Slovenia, Romania, Bulgaria, Estonia, Latvia, Lithuania and Cyprus. They have been granted membership conditional on their market economy, democratic and legal status.

${ }^{2}$ A calculation for 1990 in Layard et al (1992).

${ }^{3}$ Note that we say potential mass immigration. Actual immigration may be considerably less since low vacancy rates and regulated labor markets in the EU may prevent large scale immigration. See Lundborg (1997). 
and by the United States in 1921. The high growth rates in the developed countries have raised immigration incentives and made immigration quotas increasingly important as a policy measure. We want to illuminate the desirability of large quotas and to obtain some indications of the growth and welfare effects of, for instance, extending the NAFTA agreement to include large immigration quotas and the EU's policy of open borders towards Eastern Europe.

Basic economic intuition indicates that large welfare gains can be achieved if labor is allowed free international mobility. In studying the incentives for emigration from the formerly centrally planned economies of Eastern Europe to the EU, Layard et al (1992) suggest that the Union should stimulate growth and welfare in these countries by offering them, among other things, considerably larger immigration quotas. ${ }^{4}$ The effects of quotas on the countries of immigration, though, are far from clear. In this paper, we investigate the growth and welfare effects of immigration quotas for both source and destination countries. We also explore the effects of taxing immigrants and of allowing only rich workers to immigrate.

We use an endogenous growth model developed by Segerstrom et.al. (1990), and Grossman and Helpman (1991a) to study the implications of immigration for growing economies. In this "quality ladders" model, economic growth is driven by the R\&D decisions of profit maximizing firms, which compete in races over time to develop new higher quality products. According to Scherer (1980), 59\% of firm R\&D expenditure is, in fact, aimed at improving existing products. By focusing on the dramatic improvements over time in the quality of many goods and services, the quality ladders model provides a simple but appealing explanation for economic growth.

Most of what has been done so far on migration and growth utilizes growth models of the Solow vintage, with an exogenous given rate of technological change. ${ }^{5}$ This literature ignores the possible effects of immigration on innovation and technological change. This is, in our view, a great drawback since immigration is likely

\footnotetext{
${ }^{4}$ Free trade and foreign aid conditional on economic reform are other recommendations by Layard et al to lower migration incentives.

${ }^{5}$ See Braun (1993), Dolado, Goria and Ichino (1993) and chapter 9 in Barro and Sala-i-Martin (1995).
} 
to stimulate economic growth if workers move from regions of low-tech production (the South) to regions of high-tech production (the North). We also observe a more than proportional migration of $R \& D$ workers in the South-North direction. Thanks to recent developments in the endogenous growth literature, we are today in a position to explore how immigration influences firm behavior, technological change and economic growth.

The quality ladders model was originally constructed for analyzing other issues but we show that this model is useful for understanding the consequences of migration. Not only is there an interesting link between migration and technology, as discussed above, but our version of the quality ladders model also possesses properties that are consistent with real world observations on international migration. In the model, workers in the South have strong incentives to migrate to the North and compared to the North, the South is characterized by i) labor abundance, ii) low wages, iii) a low utility level, iv) low levels of R\&D, v) production of low-tech goods, vi) low rates of quality upgrading per time period, and, vii) production of low-price goods. Besides these highly appealing properties, we believe that a model in which growth rests on technological change is highly suitable for understanding the effects of immigration quotas. $^{6}$

The rest of the paper is organized as follows: In section 2, we present our dynamic general equilibrium North-South migration model and solve for the international migration incentives of workers. With two asymmetric countries, this model is complicated and we explore its public policy implications using computer simulations. The results of these simulations are reported in section 3. In addition to studying the effects of immigration quotas, we explore some alternative policies that may be more beneficial to the North: taxation of immigrants and selective immigration quotas. We also study the effects of population restrictions in the South and R\&D subsidies on

\footnotetext{
${ }^{6}$ Labor migration has been studied using one-country endogenous growth models. For instance, Rivera-Batiz (1994) treats immigration as an increase in the population of a single isolated country, using the Romer (1990) endogenous growth model. While this approach has the advantage of simplicity one drawback is that the incentives for migration cannot be analyzed. Another drawback is that treating migration as merely a population increase in the immigration country ignores the corresponding population decrease in the emigration country and its economic ramifications in both countries.
} 
migration incentives, growth and discounted welfare. Section 4 summarizes our findings and offers some final remarks.

\section{The Model}

\section{Some General Comments.}

We will analyze a quality ladders growth model with two structurally different countries, the North and the South. Our review of how the basic quality ladders model works will be brief so as to provide more space for describing how we extend this model. For more details concerning the basic model, see Grossman and Helpman (1991a,b).

In this model of the world economy, there is a continuum of industries with individual industries indexed by $\omega \in[0,1]$. Industries $\omega \geq \alpha$ are high-tech and situated in the North and industries $\omega<\alpha$ are low-tech and situated in the South. In the North, firms participate in high-tech $R \& D$ races and in the South, firms participate in low-tech $R \& D$ races, implying that we assume away inter-regional $R \& D$ targeting but focus solely on intra-regional targeting.

In each industry, firms are distinguished by the quality $j$ of the products they produce. Higher values of $j$ denote higher quality and $j$ is restricted to take on integer values. At time $t=0$, the state-of-the-art quality product in each industry is $j=0$, that is, some firm in each industry knows how to produce a $j=0$ quality product and no firm knows how to produce any higher quality product. To learn how to produce higher quality products, firms in each industry engage in $R \& D$ races. In general, when the state-of-the-art quality in an industry is $j$, the next winner of a $\mathrm{R} \& \mathrm{D}$ race becomes the sole producer of a $j+1$ quality product. Since firms are Bertrand price-setters, each R\&D race winner is able to price lower quality competitors out of business and take over the world market in its industry. Thus, over time, product quality improves as innovations push each industry up its quality ladder.

In each of the two countries, the North and the South (top index $\mathrm{n}$ and $\mathrm{s}$, respectively), labor is the only input in both production and research. In both countries, one unit of labor is required to produce one unit of output, regardless of quality. (In the 
North, a worker produces, say, one computer and in the South a worker produces one pair of shoes.) The native worker endowments in the two countries, $\mathrm{L}^{\mathrm{n}}$ and $\mathrm{L}^{\mathrm{s}}$, respectively, are fixed and change only with migration. Labor markets in both countries are perfectly competitive and firms are free to hire as many workers as they desire to engage in either production or research. We treat the wage rate in the South as the numeraire and let w denote the relative wage of North's workers. Free trade prevails between the two countries.

\section{Consumer Behavior}

All consumers live forever, have identical preferences and maximize discounted utility

$$
U \equiv \int_{0}^{\infty} \mathbf{e}^{-\rho t} \log \mathbf{u}(t) \mathbf{d} t
$$

where $\rho$ is the subjective discount rate and $\log \mathbf{u}(t)$ is each consumer's static utility at time t. This static utility is given by:

$$
\log \mathbf{u}(t) \equiv \int_{0}^{\alpha} \log \sum_{j}\left(\lambda^{s}\right)^{\mathbf{d}} \mathbf{d}(j, t, \omega) \mathbf{d} \omega+\int_{\alpha}^{1} \log \sum_{j}\left(\lambda^{n}\right)^{\mathbf{j}} \mathbf{d}(j, t, \omega) \mathbf{d} \omega .
$$

where $\mathrm{d}(\mathrm{j}, \mathrm{t}, \omega)$ denotes the quantity consumed of a product of quality $j$ produced in industry $\omega$ at time $t$, and $\lambda^{\mathrm{n}}, \lambda^{\mathrm{s}}>1$ represents the extent to which higher quality products improve on lower quality products in the North and the South, respectively.

At each point in time t, each consumer allocates expenditure $E$ to maximize log $\mathrm{u}(\mathrm{t})$ given the prevailing market prices. Solving this budget allocation problem yields a unit elastic demand function

$$
\mathbf{d}=\mathbf{E} / p
$$

where $d$ is quantity demanded and $p$ is the market price for the product in each industry with the lowest quality adjusted price. The quantity demanded for all other products is zero. Given this static demand behavior, each consumer chooses the path of expenditure over time to maximize (1) subject to the usual intertemporal budget constraint. Solving this optimal control problem yields 


$$
\frac{\mathbf{d E}(t)}{\mathbf{d} t} / \mathbf{E}(t)=\mathbf{r}(t)-\rho
$$

that is, a constant expenditure path is optimal if and only if the market interest rate equals $\rho$. We will restrict attention to steady state properties of the model. Then $\rho$ is the equilibrium interest rate throughout time and consumer expenditure is constant over time. We let $\mathrm{E}^{\mathrm{n}}$ and $\mathrm{E}^{\mathrm{s}}$ denote aggregate steady state consumer expenditures in the North and South, respectively.

\section{Product Markets}

Since one unit of labor produces one unit of output regardless of quality, and the Southern wage rate has been normalized to equal one, every Southern firm has a constant marginal cost equal to one and every Northern firm has a constant marginal cost equal to $\mathrm{w}$. When a non-leader firm innovates, it becomes the single quality leader in its industry. We assume that Southern workers are not capable of doing high-tech R\&D which implies that low-tech firms only target their R\&D resources at developing better low-tech products. While Northern workers are capable of doing low-tech R\&D, they choose not to do so since the wage in the South is lower; consequently high-tech firms target their R\&D resources at developing better high-tech products. Since lowtech firms are located in the South and high-tech firms in the North, targeting takes place across firms within the same country. As shown by Grossman and Helpman (1991a,b), it does not pay for industry leaders to do R\&D and improve their own products. Hence, the identity of industry leaders change whenever innovation occurs.

Consider the profits earned by a Northern leader selling to Northern consumers and competing against a Northern follower. With the follower charging a price of $w$, the lowest price such that losses are avoided, the new quality leader earns instantaneous profits

$$
\pi^{n}(p)= \begin{cases}(p-\mathbf{w}) \mathbf{E}^{n} / p, & p \leq \lambda^{n} \mathbf{w} \\ 0, & p \succ \lambda^{n} \mathbf{w}\end{cases}
$$


where $\mathrm{p}$ is the quality leader's price. These profits are maximized by choosing $\mathrm{p}=\lambda^{\mathrm{n}} \mathrm{w}$. Therefore, this quality leader earns as a reward for its innovative activity the profit flow $\left(1-1 / \lambda^{n}\right) \mathrm{E}^{\mathrm{n}}$, and none of the other firms in the industry can do any better than break even by selling nothing at all to Northern consumers. When the firm sells to Southern consumers, it earns the profit flow $\left(1-1 / \lambda^{n}\right) E^{s}$ so that total profits are $\pi^{n}=\left(1-1 / \lambda^{n}\right)\left(E^{n}\right.$ $\left.+E^{s}\right)$. Likewise, a Southern firm earns the profit flow $\pi^{\mathrm{s}}=\left(1-1 / \lambda^{\mathrm{s}}\right)\left(\mathrm{E}^{\mathrm{n}}+\mathrm{E}^{\mathrm{s}}\right)$ from selling in both the North and the South.

We allow for differences between the North and the South in R\&D subsidy rates, endowments of labor, R\&D abilities of workers and ownership shares of world assets.

\section{$R \& D$ Activities by Firms.}

The returns to engaging in $R \& D$ are independently distributed across industries and over time. Consider the R\&D behavior of firms in the North (corresponding conditions apply to the South). In industry $\omega$ at time t, let $\ell_{i}^{n}$ denote firm i's employment of R\&D labor and let $\ell^{\mathrm{n}} \equiv \sum_{\mathrm{i}} \ell_{\mathrm{i}}^{\mathrm{n}}$ denote the industry-wide R\&D employment. Firm i's instantaneous probability of winning the $R \& D$ race and becoming the next quality leader is assumed to equal $\ell_{i}{ }^{n} /\left(a+b \ell^{n}\right)$, where $a \succ 0$ and $b \geq 0$ are $R \& D$ technology parameters. Individual $R \& D$ firms behave competitively and treat $\ell^{\mathrm{n}}$ as given, not influenced by their choice of $\ell_{i}^{n}$ [as in Dixit (1988)].

This R\&D formulation with $b=0$ is used in Grossman and Helpman (1991a,b) and corresponds to assuming constant returns to $R \& D$. By allowing for $b>0$, we consider $a$ broader range of possibilities. With $b>0$, each firm's instantaneous probability of success is a decreasing function of industry-level R\&D effort. One way to interpret this property is that when firms do more $R \& D, R \& D$ duplication becomes more likely and success in the R\&D laboratory becomes less likely to translate into profits in the relevant product market. Individual R\&D firms can be hurt when other firms do more $R \& D$ if it becomes less likely that they will be rewarded for $R \& D$ success. It is this instantaneous probability of being rewarded in the relevant product market that we are ultimately concerned with. The instantaneous probability that some firm will be rewarded for $R \& D$ success is $\ell^{n} /\left(a+b \ell^{n}\right)$. When $b>0$, this is a strictly concave function and there are decreasing returns to $R \& D$ at the industry level. 
R\&D is only undertaken by Northern firms in industries with a Northern leader and $R \& D$ is only undertaken by Southern firms in industries with a Southern leader. Thus we can distinguish between Northern and Southern R\&D races. Let $v^{\mathrm{n}}$ and $v^{\mathrm{s}}$ denote the expected discounted rewards for winning Northern and Southern R\&D races, respectively. Likewise, let $\mathrm{s}^{\mathrm{n}}$ and $\mathrm{s}^{\mathrm{s}}$ denote $\mathrm{R} \& \mathrm{D}$ subsidy rates chosen by the Northern and Southern governments, respectively. Then, in Northern R\&D races, each firm $\mathrm{i}$ chooses its R\&D employment $\ell_{i}^{n}$ to maximize instantaneous profits $v^{n} \ell_{i}^{n} /\left(a+b \ell^{n}\right)-w(1-$ $\left.\mathrm{s}^{\mathrm{n}}\right) \ell_{\mathrm{i}}^{\mathrm{n}}$, where $\ell^{\mathrm{n}} \equiv \sum_{i} \mathrm{l}_{i}^{\mathrm{n}}$ is the industry-wide employment of labor in a Northern R\&D race. And in Southern $R \& D$ races, each firm $i$ chooses its $R \& D$ employment $\ell_{i}^{s}$ to maximize instantaneous profits $v^{s} \ell_{i}^{s} /\left(a+b \ell^{s}\right)-\left(1-s^{s}\right) \ell_{i}^{s}$, where $\ell^{s} \equiv \sum_{i} l_{i}^{s}$ is the industry-wide employment of labor in a Southern $R \& D$ race.

In a steady state equilibrium, firms will determine their R\&D levels so that in the Northern country $v^{n}=w\left(a+b \ell^{n}\right)\left(1-s^{n}\right)$, and applying the same reasoning to the Southern $R \& D$ firm's maximization problem yields $v^{s}=\left(a+b \ell^{s}\right)\left(1-s^{s}\right)$. We can now see the advantage of allowing for diminishing returns to $R \& D(b>0)$. When $b>0$, we obtain a positive relationship between the reward for winning a $R \& D$ race $(v)$ and how much $R \& D$ is done $(\ell)$. Slightly higher rewards lead to slightly more $R \& D$. When $b=0, R \& D$ behavior becomes infinitely sensitive to the size of the reward. For example, starting from $v^{\mathrm{n}}=\mathrm{wa}\left(1-\mathrm{s}^{\mathrm{n}}\right)$, the slightest increase in $v^{\mathrm{n}}$ leads firms to want to choose $\ell^{\mathrm{n}}=+\infty$ and the slightest decrease in $v^{\mathrm{n}}$ leads firms to want to choose $\ell^{\mathrm{n}}=0$. In the interest of obtaining reasonable results, we focus mainly on the properties of the model when $b$ is greater than zero. ${ }^{7}$

We will now determine the equilibrium rewards for winning R\&D races. From equation (4), in any steady state equilibrium, the market interest rate must equal $\rho$. Not only must we discount profits using $\rho$, but we must also take into account that every quality leader is eventually driven out of business by another firm that innovates. For a Northern leader, this occurs with instantaneous probability $\ell^{\mathrm{n}} /\left(\mathrm{a}+\mathrm{b} \ell^{\mathrm{n}}\right)$ and for a Southern leader, this occurs with instantaneous probability $\ell^{\mathrm{s}} /\left(\mathrm{a}+\mathrm{b} \ell^{\mathrm{s}}\right)$. Thus we obtain as equilibrium R\&D conditions:

\footnotetext{
${ }^{7}$ The unattractive implications of assuming $b=0$ are explored in more detail in Davidson and Segerstrom (1998).
} 


$$
v^{n}=\frac{\left(1-1 / \lambda^{n}\right)\left(\mathbf{E}^{n}+\mathbf{E}^{s}\right)}{\rho+\ell^{n} /\left(a+b \ell^{n}\right)}=\mathbf{w}\left(a+b \ell^{n}\right)\left(1-\mathbf{s}^{n}\right)
$$

and

$$
v^{s}=\frac{\left(1-1 / \lambda^{s}\right)\left(\mathbf{E}^{n}+\mathbf{E}^{s}\right)}{\rho+\ell^{s}\left(a+b \ell^{s}\right)}=\left(a+b \ell^{s}\right)\left(1-\mathbf{s}^{s}\right) .
$$

These two equations capture the idea that, in equilibrium, Northern leaders are eventually driven out of business by Northern innovation, and Southern leaders are eventually driven out of business by Southern innovation.

\section{Labor Markets}

The proportion 1- $\alpha$ of industries have Northern leaders. Each Northern leader employs $E^{n} / \lambda^{n} w$ workers for domestic production and $E^{s} / \lambda^{n} w$ workers for export production. Northern firms do R\&D and employ $\ell^{\mathrm{n}}$ workers per industry. Thus, full employment of Northern labor $\mathrm{L}^{\mathrm{n}}$ implies that

$$
\mathbf{L}^{n}=(1-\alpha)\left(\mathbf{E}^{n} / \lambda^{n} \mathbf{w}+\mathbf{E}^{s} / \lambda^{n} \mathbf{w}+\ell^{n}\right) .
$$

The proportion $\alpha$ of industries have Southern quality leaders. Each Southern leader employs $E^{s} / \lambda^{s}$ workers for domestic production and $E^{n} / \lambda^{n}$ workers for export production. In each of the $\alpha$-industries, Southern firms do R\&D and employ $\ell^{\mathrm{s}}$ workers per industry. Thus, full employment of Southern labor $\mathrm{L}^{\mathrm{s}}$ implies that

$$
\mathbf{L}^{s}=\alpha\left(\mathbf{E}^{s} / \lambda^{s}+\mathbf{E}^{n} / \lambda^{s}+\ell^{s}\right) .
$$

\section{Consumer Expenditures}

To close the model, we need to determine consumer expenditures in each country. In the Northern country, steady state consumer expenditure $\mathrm{E}^{\mathrm{n}}$ must equal wage income plus interest income on assets owned minus taxes paid to finance the Northern R\&D subsidy. 
The value of all assets owned in the world economy $\mathrm{A}^{\mathrm{w}}$ equals the stock market value of all the leader firms in the world economy, i.e. $A^{w}=\alpha v^{s}+(1-\alpha) v^{n}$. Substituting for $v^{n}$ and $\mathrm{v}^{\mathrm{s}}$ using (6) and (7) respectively, we obtain

$$
A^{w}=\alpha\left(a+b \ell^{s}\right)\left(1-\mathbf{s}^{s}\right)+(1-\alpha) \mathbf{w}\left(a+b \ell^{n}\right)\left(1-\mathbf{s}^{n}\right) .
$$

Let $\phi$ denote the share of world assets owned by Northern country consumers. Then $\rho \phi \mathrm{A}^{\mathrm{w}}$ is Northern interest income and $\rho(1-\phi) \mathrm{A}^{\mathrm{w}}$ is Southern interest income. To determine the Northern tax revenues that need to be raised to finance the Northern R\&D subsidies, we note first that $\ell^{\mathrm{n}}(1-\alpha)$ workers do $R \& D$ in the Northern country. These workers are paid $\mathrm{w} \ell^{\mathrm{n}}(1-\alpha)$ and the government pays the fraction $\mathrm{s}^{\mathrm{n}}$ of this wage bill. Thus the Northern government must raise $s^{n} w \ell^{n}(1-\alpha)$ in taxes to finance the $R \& D$ subsidy. Putting this all together, Northern consumer expenditure $E^{n}=w L^{n}+\rho \phi A^{w}-$ $\mathrm{s}^{\mathrm{n}} \mathrm{w} \ell^{\mathrm{n}}(1-\alpha)$ becomes:

$$
\mathbf{E}^{n}=\mathbf{w} \mathbf{L}^{n}+\rho \phi\left[\alpha\left(a+b \ell^{s}\right)\left(1-\mathbf{s}^{s}\right)+(1-\alpha) \mathbf{w}\left(a+b \ell^{n}\right)\left(1-\mathbf{s}^{n}\right)\right]-\mathbf{s}^{n} \mathbf{w} \ell^{n}(1-\alpha) .
$$

In the South, $\ell^{\mathrm{s}} \alpha$ workers do $R \& D$, are paid $\ell^{\mathrm{s}} \alpha$ and the Southern government pays the fraction $s^{s}$ of this wage bill. Thus, the Southern government must raise $s^{s} \ell^{s} \alpha$ in taxes to finance its R\&D subsidy. Since Southern consumer expenditures must also equal wage income plus interest income on assets owned minus taxes paid to finance the Southern R\&D subsidy, we obtain:

$$
\mathbf{E}^{s}=\mathbf{L}^{s}+\rho(1-\phi)\left[\alpha\left(a+b \ell^{s}\right)\left(1-\mathbf{s}^{s}\right)+(1-\alpha) \mathbf{w}\left(a+b \ell^{n}\right)\left(1-\mathbf{s}^{n}\right)\right]-\mathbf{s}^{s} \ell^{s} \alpha .
$$

We have now completed the presentation of the two-country endogenous growth model and it is useful at this stage to sum it up. We have derived six equations; Northern and Southern R\&D conditions (Equations (6) and (7)), Northern and Southern labor market 
conditions (Equations (8) and (9)), and Northern and Southern expenditure conditions (Equations (11) and (12)). Thus we have six equations in five unknowns $\left(\mathrm{E}^{\mathrm{n}}, \mathrm{E}^{\mathrm{s}}, \ell^{\mathrm{n}}, \ell^{\mathrm{s}}\right.$ and w). However, since the model is a general equilibrium model, Walras Law applies, and if five of the six equations are satisfied, the sixth equation must also be satisfied. Thus we can solve the model for a steady state equilibrium by solving a system of five equations in five unknowns.

\section{Welfare and Growth}

We calculate consumer welfare (discounted consumer utility) starting from time $t=0$ in each of the two countries. Remember that all consumers are assumed to have identical preferences. Consider first the utility of a Northern consumer with steady state expenditure $\mathrm{e}^{\mathrm{n}}$. At any point in time, this consumer only buys the highest quality product in each industry, and from (3), this consumer's static demand function is given by $d(j, t, \omega)=e^{n} / p^{n}(j, t, \omega)$. This consumer buys from a Northern leader charging the price $\lambda^{n}$ $\mathrm{w}$ in $(1-\alpha)$ industries and from a Southern leader charging the price $\lambda^{\mathrm{s}}$ in $\alpha$ industries. Before we substitute this information into (2) we note that, in this equation, $\int_{0}^{\alpha} \log \lambda^{\mathrm{s}} \mathrm{d} \omega$ $+\int_{\alpha}{ }^{1} \log \lambda^{\mathrm{n}} \mathrm{d} \omega=\mathrm{t}\left[\alpha \mathrm{I}^{\mathrm{s}} \log \lambda^{\mathrm{s}}+(1-\alpha) \mathrm{I}^{\mathrm{n}} \log \lambda^{\mathrm{n}}\right]$ where $\mathrm{I}^{\mathrm{s}}$ and $\mathrm{I}^{\mathrm{n}}$ are the steady state industrywide instantaneous probability of R\&D success in the South and the North, respectively. [See Grossman and Helpman (1991a, p. 50)]. In $\alpha$ industries, the instantaneous probability of $R \& D$ success is $\ell^{s} /\left(a+b \ell^{s}\right)$ and in 1- $\alpha$ industries, the instantaneous probability of $R \& D$ success is $\ell^{\mathrm{n}} /\left(\mathrm{a}+\mathrm{b} \ell^{\mathrm{n}}\right)$. Substituting all the above information into (2) yields the Northern consumer's instantaneous utility

$$
\log \mathbf{u}^{n}(t)=t\left(\alpha \frac{\ell^{s}}{\left(a+b \ell^{s}\right)} \log \lambda^{s}+(1-\alpha) \frac{\ell^{n}}{\left(a+b \ell^{n}\right)} \log \lambda^{n}\right)+\alpha \log \left(\mathbf{e}^{n} / \lambda^{s}\right)+(1-\alpha) \log \left(\mathbf{e}^{n} / \lambda^{n} \mathbf{w}\right) .
$$

For a Southern consumer with steady state expenditure $\mathrm{e}^{\mathrm{s}}$, the situation is slightly different. This consumer buys from a Northern leader charging the price $\lambda^{\mathrm{n}} \mathrm{w}$ in $(1-\alpha)$ industries and from a Southern leader charging the price $\lambda^{\mathrm{s}}$ in $\alpha$ industries. Substituting this information into (2), along with the redefined integral, yields the Southern consumer's instantaneous utility: 
$\log \mathbf{u}^{s}(t)=t\left(\alpha \frac{\ell^{s}}{\left(a+b \ell^{s}\right)} \log \lambda^{s}+(1-\alpha) \frac{\ell^{n}}{\left(a+b \ell^{n}\right)} \log \lambda^{n}\right)+\alpha \log \left(\mathbf{e}^{s} / \lambda^{s}\right)+(1-\alpha) \log \left(\mathbf{e}^{s} / \lambda^{n} \mathbf{w}\right)$.

Substituting (13) and (14) into (1), we obtain discounted welfare expressions for both Northern and Southern consumers:

$$
W^{n}\left(\mathbf{e}^{n}\right) \equiv \rho U^{n}\left(\mathbf{e}^{n}\right)=\left(\alpha \frac{\ell^{s}}{a+b \ell^{s}} \log \lambda^{s}+(1-\alpha) \frac{\ell^{n}}{a+b \ell^{n}} \log \lambda^{n}\right) / \rho+\alpha \log \left(\mathbf{e}^{n} / \lambda^{s}\right)+(1-\alpha) \log \left(\mathbf{e}^{n} / \lambda^{n} \mathbf{w}\right)
$$

and

$$
W^{s}\left(\mathbf{e}^{s}\right) \equiv \rho U^{s}\left(\mathbf{e}^{s}\right)=\left(\alpha \frac{\ell^{s}}{a+b \ell^{s}} \log \lambda^{s}+(1-\alpha) \frac{\ell^{n}}{a+b \ell^{n}} \log \lambda^{n}\right) / \rho+\alpha \log \left(\mathbf{e}^{s} / \lambda^{s}\right)+(1-\alpha) \log \left(\mathbf{e}^{s} / \lambda^{n} \mathbf{w}\right) .
$$

Comparing (13) and (14), we see that the expressions are identical, except for expenditures, $e^{\mathrm{n}}$ and $\mathrm{e}^{\mathrm{s}}$. In particular, the time derivatives of $\log \mathrm{u}^{\mathrm{n}}(\mathrm{t})$ and $\log \mathrm{u}^{\mathrm{s}}(\mathrm{t})$ are identical. This means that individuals in both countries must experience $i$ dentical growth rates in consumer utility. In general, $\mathrm{e}^{\mathrm{n}}$ and $\mathrm{e}^{\mathrm{s}}$ differ, implying that utility levels differ. Since the conclusion on identical utility growth applies even when $\ell^{\mathrm{n}} \neq \ell^{\mathrm{s}}$, it does not hinge on R\&D subsidy policies. Both countries experience identical steady state equilibrium growth rates even when they adopt different R\&D subsidy policies, have different population sizes, produce different types of goods, etc.

To understand the intuition behind this result, we must remember that both countries are connected by trade. This means that when any firm in the world innovates, consumers in both countries buy the new higher quality product. Since consumers in both countries benefit from any innovation, both countries must grow at the same rate. Differences in R\&D subsidies cause international differences in utility levels, not utility growth rates. Thus the distinction between growth and level effects that is emphasized in the exogenous growth theory literature is also important when analyzing this endogenous growth model. 


\section{Migration Incentives}

Given that consumer utility grows at the same rate in the two countries, if there are any incentives for international migration in a steady state equilibrium, they must be present at time $\mathrm{t}=0$. Thus, to determine migration incentives, we will compare the static utilities of a Southern worker at $\mathrm{t}=0$ with the static utility this worker would get from working in the North. To make this comparison, we first need to calculate how consumer expenditure differs in the two countries. In the North, total income before taxes equals $\mathrm{wL}^{\mathrm{n}}+\rho \phi \mathrm{A}^{\mathrm{w}}$ and total taxes equal $\mathrm{ws}^{\mathrm{n}} \ell^{\mathrm{n}}(1-\alpha)$. We will assume that taxes are spread evenly across all income earners (wage as well as interest income). Then a Northern worker with one unit of labor pays taxes $\left[\mathrm{ws}^{\mathrm{n}} \ell^{\mathrm{n}}(1-\alpha)\right]\left[\mathrm{w} /\left(\mathrm{wL}^{\mathrm{n}}+\rho \phi \mathrm{A}^{\mathrm{w}}\right)\right]$. Since this worker earns before tax income of $\mathrm{w}$, (after tax) steady state consumer expenditure for this Northern worker is $\mathrm{e}^{\mathrm{nw}} \equiv \mathrm{w}\left[1-\left(\mathrm{ws}^{\mathrm{n}} \ell^{\mathrm{n}}(1-\alpha)\right) /\left(\mathrm{wL}^{\mathrm{n}}+\rho \phi \mathrm{A}^{\mathrm{w}}\right)\right]$. Using similar calculations, a Southern worker with one unit of labor has (after tax) steady state consumer expenditure $\mathrm{e}^{\mathrm{sw}} \equiv 1-\left(\mathrm{s}^{\mathrm{s}} \ell^{\mathrm{s}} \alpha\right) /\left(\mathrm{L}^{\mathrm{s}}+\rho(1-\phi) \mathrm{A}^{\mathrm{w}}\right)$. Substituting these expenditure expressions into (13) and (14) and evaluating at $\mathrm{t}=0$, we obtain the migration incentive measure

$$
\mathbf{M} \equiv \alpha \log \left(\mathbf{e}^{n w} / \lambda^{s}\right)+(1-\alpha) \log \left(\mathbf{e}^{n w} / \lambda^{n} \mathbf{w}\right)-\alpha \log \left(\mathbf{e}^{s w} / \lambda^{s}\right)-(1-\alpha) \log \left(\mathbf{e}^{s w} / \lambda^{n} \mathbf{w}\right)
$$

If $\mathrm{M}$ is positive, then workers would gain by moving from the South to the North.

\section{National Income Accounting}

Since investment and government expenditure both equal zero and since international trade is balanced, nominal gross national product in each country equals consumption expenditure, i.e. $\mathrm{GNP}^{\mathrm{n}}=\mathrm{E}^{\mathrm{n}}$ and $\mathrm{GNP}^{\mathrm{s}}=\mathrm{E}^{\mathrm{s}}$. In a steady-state equilibrium, $\mathrm{E}^{\mathrm{n}}$ and $\mathrm{E}^{\mathrm{s}}$ are constants and thus nominal GNP does not change over time in either the North or the South.

However, real GNP rises over time as the quality of products improve. With nominal GNP constant in a steady-state equilibrium, we must have deflation in terms of the quality adjusted, i.e. real, prices. To see this, we need to first solve for the general relationship between innovation and deflation. When the R\&D intensity is I, a typical $\mathrm{R} \& \mathrm{D}$ race has time duration $1 / \mathrm{I}$. The relationship between the quality-adjusted price after the innovation $\left(\mathrm{P}_{\mathrm{ra}}\right)$ and before the innovation $\left(\mathrm{P}_{\mathrm{rb}}\right)$ is $\mathrm{P}_{\mathrm{ra}}=\mathrm{P}_{\mathrm{rb}} / \lambda$ in both countries. 
It follows that a real price index $\mathrm{P}_{\mathrm{r}}(\mathrm{t})$ must satisfy $\mathrm{P}_{\mathrm{r}}(1 / \mathrm{I})=1 / \lambda \mathrm{P}_{\mathrm{r}}(0)=\mathrm{P}_{\mathrm{r}}(0) \exp [\Pi / \mathrm{I}]$ where $\Pi$ represents the inflation rate. Solving yields the quality adjusted inflation rate as $\Pi=-\mathrm{I} \log \lambda$. Thus, the innovation rate $\mathrm{I}$ is associated with a negative rate of inflation.

Using this innovation-deflation relationship, we can solve for real GNP in both countries. Let $\mathrm{P}_{\mathrm{r}, \alpha}(\mathrm{t})$ and $\mathrm{P}_{\mathrm{r}, 1-\alpha}(\mathrm{t})$ be the price indexes that apply to the low-tech industries in the South and the high-tech industries in the North, respectively. To simplify, assume that both price indexes take on a unity value at time $t=0$. The real GNP at time $\mathrm{t}$ in the North equals $\alpha \mathrm{E}^{\mathrm{n}} / \mathrm{P}_{\mathrm{r}, \alpha}(\mathrm{t})+(1-\alpha) \mathrm{E}^{\mathrm{n}} / \mathrm{P}_{\mathrm{r}, 1-\alpha}(\mathrm{t})$, or

$$
G N P_{r}^{n}=\mathbf{E}^{n}\left(\alpha \mathbf{e}^{t I^{s} \log \lambda^{s}}+(1-\alpha) \mathbf{e}^{t I^{n} \log \lambda^{n}}\right) .
$$

In the corresponding way we obtain real GNP in the South as

$$
G N P_{r}^{s}=\mathbf{E}^{s}\left(\alpha \mathbf{e}^{t I^{s} \log \lambda^{s}}+(1-\alpha) \mathbf{e}^{t I^{n} \log \lambda^{n}}\right) .
$$

Clearly, real GNP growth rates are identical in the two countries. In the more relevant case where $\mathrm{I}^{\mathrm{n}} \log \lambda^{\mathrm{n}}>\mathrm{I}^{\mathrm{s}} \log \lambda^{\mathrm{s}}$, that is, when he North is more innovative than the South, the growth rate in the two countries gradually increases over time and asymptotically approaches $\mathrm{I}^{\mathrm{n}} \log \lambda^{\mathrm{n}}$. The long run real GNP growth rate is thus determined in the North. This is so since the higher innovation rate in the North implies that the real (i.e. quality-adjusted) prices of Northern products over time falls faster than the real prices of Southern products. Eventually, consumers will extract most of their utility from consuming goods that are produced in the North. Hence, the relative contribution of the South to the world's real GNP falls over time.

\section{3. $R \operatorname{esu} l t \mathbf{s}$}

We are now ready to analyze how international differences generate incentives for international migration. We solve the system of five equations $((6),(7),(8),(9)$ and (11)) in five unknowns ( $E^{\mathrm{n}}, \mathrm{E}^{\mathrm{s}}, \ell^{\mathrm{n}}, \ell^{\mathrm{s}}$ and $\mathrm{w}$ ) and the variables in (13) through (19) follow straightforwardly. This system of non-linear equations is not analytically 
tractable and thus we will use computer simulations to shed light on the model's properties. An important advantage of this approach is that by evaluating the model under what we believe are plausible parameter values, we are able to rule out some theoretical possibilities as being unrealistic.

The main reason why our model is complicated is that we allow for differences across countries. In previous work on the relationship between trade and growth by Rivera-Batiz and Romer (1991a,b), it was assumed that both trading countries were identical in every respect. Two country endogenous growth models become considerably more complicated when either structural or public policy differences lead to cross country differences in the endogenous variables. Such differences, more specifically in relative utilities, however, are necessary for migration incentives to be present.

In our computer simulations, we use as benchmark parameter values $\lambda^{\mathrm{n}}=1.28$, $\lambda^{\mathrm{s}}=1.15, \rho=.05, \alpha=0.5, \mathrm{~L}^{\mathrm{n}}=1, \mathrm{~L}^{\mathrm{s}}=2, \mathrm{~b}=1, \mathrm{~s}^{\mathrm{n}}=\mathrm{s}^{\mathrm{s}}=0.1, \mathrm{a}=4.75$ and $\phi=0.9$. The economic interpretation of these parameter choices is as follows: $\lambda^{\mathrm{n}}=1.28$ and $\lambda^{\mathrm{s}}=1.15$ means that each innovation represents a $28 \%$ and a $15 \%$ improvement in the North and South, respectively. Consumers are willing to pay $28 \%$ more for each new higher quality hightech product and $15 \%$ more for each new higher quality low-tech product. Given (4), $\rho=.05$ implies that the steady state market interest rate is $5 \% . \mathrm{L}^{\mathrm{n}}=1.0$ and $\mathrm{L}^{\mathrm{s}}=2.0$, together with $\alpha=.5$ implies that twice as much labor is employed per industry in the South than in the North.

To interpret the diminishing returns to $R \& D$ effort parameter $b$, first note that the industry-wide instantaneous probability of $R \& D$ success is $I^{n} \equiv \ell^{n} /\left(a+b \ell^{n}\right)$ and $I^{\mathrm{s}} \equiv \ell^{\mathrm{s}} /\left(\mathrm{a}+\mathrm{b} \ell^{\mathrm{s}}\right)$. This implies that the time duration of a $\mathrm{R} \& \mathrm{D}$ race is exponentially distributed and that the expected duration is $1 / \mathrm{I}^{\mathrm{n}}=\left(\mathrm{a}+\mathrm{b} \ell^{\mathrm{n}}\right) / \ell^{\mathrm{n}}$ and $1 / \mathrm{I}^{\mathrm{s}}=\left(\mathrm{a}+\mathrm{b} \ell^{\mathrm{s}}\right) / \ell^{\mathrm{s}}$. Letting $\ell^{\mathrm{n}}$ and $\ell^{\mathrm{s}}$ approach $+\infty$, we obtain that $\mathrm{b}=1$ years is the shortest possible expected duration for an $R \& D$ race in each country. Subsidy rates $s^{n}=s^{s}=0.1$ means that both countries support R\&D by $10 \%$. Given the benchmark parameter values $\lambda^{\mathrm{n}}=1.28, \lambda^{\mathrm{s}}=1.15$, $\rho=.05, \mathrm{~L}^{\mathrm{n}}=1.0, \mathrm{~L}^{\mathrm{s}}=2.0, \mathrm{~b}=1$ and $\mathrm{s}^{\mathrm{h}}=\mathrm{s}^{\mathrm{f}}=0.1, \mathrm{a}=4.75$ implies a .51 percent growth rate of GNP. For the U.S. over the period 1929-82, Denison (1985, p. 30) finds that the rate of GNP growth attributable to advances in knowledge is on the order of one half percent per year. Finally, $\phi=.9$ means that the North owns $90 \%$ of the world's assets. 
With these parameter values, we obtain the benchmark solution given in column 2 of Table 1. In this table are reported industry R\&D employment levels $\left(\ell^{\mathrm{n}}\right.$ and $\left.\ell^{\mathrm{s}}\right)$, consumer expenditures $\left(\mathrm{E}^{\mathrm{n}}\right.$ and $\left.\mathrm{E}^{\mathrm{s}}\right)$, the common steady state utility growth rate $\left(\alpha \ell^{\mathrm{s}} /\left(\mathrm{a}+\mathrm{b} \ell^{\mathrm{s}}\right) \log \lambda^{\mathrm{s}}+(1-\alpha) \ell^{\mathrm{n}} /\left(\mathrm{a}+\mathrm{b} \ell^{\mathrm{n}}\right) \log \lambda^{\mathrm{n}}\right)$, the relative wage of Northern workers (w), the migration incentive measure (M), as well as several welfare measures.We measure the welfare of native workers by calculating the discounted utility of a worker with one unit of labor to supply and no asset holdings $\left(\mathrm{W}^{\mathrm{n}}\left(\mathrm{e}^{\mathrm{nw}}\right)\right.$ and $\left.\mathrm{W}^{\mathrm{s}}\left(\mathrm{e}^{\mathrm{sw}}\right)\right)$. To measure the welfare of capital owners in the North, we calculate the discounted utility of an individual that has no labor income but owns the share $\phi$ of world assets. This individual would have after tax expenditure $\mathrm{e}^{\mathrm{nc}}=\rho \phi \mathrm{A}^{\mathrm{w}}\left[1-\left(\mathrm{ws}^{\mathrm{n}} \ell^{\mathrm{n}}(1-\alpha)\right) /\left(\mathrm{wL}^{\mathrm{n}}+\rho \phi \mathrm{A}^{\mathrm{w}}\right)\right]$ and discounted utility $\mathrm{W}^{\mathrm{n}}\left(\mathrm{e}^{\mathrm{nc}}\right)$. The discounted welfare of capital owners in the South is similarly calculated as $\mathrm{W}^{\mathrm{s}}\left(\mathrm{e}^{\mathrm{sc}}\right)$ where $\mathrm{e}^{\mathrm{sc}}=\rho(1-\phi) \mathrm{A}^{\mathrm{w}}\left[1-\left(\mathrm{s}^{\mathrm{s}} \ell^{\mathrm{s}}(1-\alpha)\right) /\left(\mathrm{L}^{\mathrm{s}}+\right.\right.$ $\left.\left.\rho(1-\phi) A^{w}\right)\right]$. Finally, we are also interested in how the welfare of workers with significant asset holdings (rich workers) are affected by immigration. The discounted welfare of a rich native worker in the North is measured by $\mathrm{W}^{\mathrm{n}}\left(\mathrm{e}^{\mathrm{rw}}\right)$ where $\mathrm{e}^{\mathrm{rw}}=\mathrm{E}^{\mathrm{n}}-\mathrm{w} \Delta \mathrm{L}^{\mathrm{n}}$ and $\Delta \mathrm{L}^{\mathrm{n}}$ is the increase in the Northern labor force due to migration.

The correctness of the results reported in Table 1 can be directly verified by plugging these solution values back into equations (6), (7), (8), (9), (11) and (12).

\section{Effects of Population Restrictions in the South.}

When a worker migrates from the South to the North, the population decreases in the South and increases in the North. As a prelude to analyzing the effects of migration, we first study the effects of a population decrease in the South, by itself. This exercise sheds important light on how the model works. We are able to solve for the effects of a population decrease in the South on the R\&D investments decision of firms in both countries and the concomitant effects on relative wages, growth, welfare and migration incentives. Population restrictions in less developed countries are also interesting to study from a policy point of view since restricting populations has been an objective of the World Bank and other international organizations, as well as of many governments in the less developed countries.

In column 3 of Table 1, the steady-state solution is presented when $\mathrm{L}^{\mathrm{s}}$ decreases 
from 2.00 to 1.95. A smaller Southern labor force implies lower consumer expenditure $\mathrm{E}^{\mathrm{s}}$ since there are fewer Southern workers earning wage income. As expenditures drops, demand for goods and production labor fall in the North and to maintain full employment of labor, it follows from (8) that the relative wage of Northern workers $\mathrm{w}$ must fall to clear the labor market. If the relative wage $\mathrm{w}$ falls enough so that total demand for Northern production labor $\left(\mathrm{E}^{\mathrm{n}}+\mathrm{E}^{\mathrm{s}}\right) / \mathrm{w} \lambda^{\mathrm{n}}$ remains unchanged, then (6) and (8) imply that the Northern labor devoted to $R \& D \ell^{n}$ remains unchanged. This is exactly what happens when the Southern labor force decreases. Not surprisingly, the drop in the relative wage of Northern workers w leads to a decrease in Northern consumer expenditure $\mathrm{E}^{\mathrm{n}}$.

Since consumer expenditure falls in both countries, the demand for Southern goods $\left(E^{n}+E^{s}\right) / \lambda^{n}$ and the profits earned by Southern firms both decrease. It follows from the R\&D condition (7) that Southern firms devote less resources to R\&D. Less R\&D effort in the South, in turn, lowers each consumer's utility growth rate (from .01176 to $.01159 \%$ ) and the common GNP growth rate (from .51086 to $.50326 \%$ ). From (10), a lower Southern R\&D effort $\ell^{\mathrm{s}}$ and a lower relative wage w of Northern workers both contribute to lowering the value of world assets $\mathrm{A}^{\mathrm{w}}$, which given (11) and (12), further reduces expenditure in both countries.

It follows that a decrease in the Southern labor force $\mathrm{L}^{\mathrm{s}}$ lowers the discounted welfare of Northern workers because the world economy grows more slowly and Northern workers earn a lower relative wage. Interestingly, the same developments increase the discounted welfare of Southern workers. The lower Northern relative wage w benefits Southern workers as the consumer price index $\alpha \lambda^{\mathrm{s}}+(1-\alpha) \lambda^{\mathrm{n}} \mathrm{w}$ falls due to imported goods becoming cheaper. The computer simulations reveal that the benefit to Southern workers from lower consumer prices more than offsets their reduced utility growth rate. Of course, since profits decrease, asset holders in both countries become poorer when $\mathrm{L}^{\mathrm{s}}$ decreases. Thus, capital owners in both countries lose when the South shrinks in size.

For an individual that obtains labor income but not asset income, his/her migration incentives are determined by comparing the utility derived from working in the North with the utility derived from working in the South. In the benchmark solution, migration incentives are present since the utility level of a worker is higher in the North 
than in the South. A decrease in the Southern labor force clearly reduces the incentive for Southern workers to emigrate to the North since the discounted welfare of each Northern worker falls and the discounted welfare of each Southern worker rises.

\section{Effects of an Immigration Quota in the North}

Since population restrictions in the South actually lower growth and welfare in the North, we now ask if a better strategy (for the North) is to allow Southern workers to enter the Northern labor market. In the simulations, we capture the effects of international worker migration from the South to the North by lowering the Southern population from 2.00 to 1.95 and raising the Northern population from 1.00 to 1.05 . This represents an immigration quota of 0.05 . The simulation results are presented in column 4 of Table 1.

It is useful to first compare the migration simulation results (in column 4) with the Southern population decrease results (in column 3). In both cases, the Southern labor supply is the same $\left(L^{s}=1.95\right)$. Since (7) and (9) together uniquely determine world expenditure and Southern R\&D employment for given $\ell^{\mathrm{s}}$, world expenditure and Southern R\&D employment must be the same in both cases. When workers migrate to the North, this increases Northern consumer expenditure but this is exactly offset by a corresponding expenditure decrease in the South. By increasing the Northern labor supply, South to North migration also depresses the Northern relative wage w. Given that world consumer expenditure does not change and w drops, (6) implies that migration must increase Northern R\&D employment and as a result, the common utility growth rate in both countries (compared to the population restriction case).

Comparing the migration simulation results to the benchmark "no-migration" case (column 2), we find that, by raising the Northern labor supply and lowering the Southern labor supply, migration significantly decreases the Northern relative wage w. The size of this wage decrease is reflected in the fact that total Northern consumer expenditure falls even though migration increases the total number of Northern wage earners. Since migration decreases Southern labor supply, not surprisingly Southern consumer expenditure also falls. Southern firms respond to the decrease in world consumer expenditure by decreasing their R\&D effort $\ell^{\mathrm{s}}$. But the big drop in wages makes $R \& D$ more attractive in the North and firms respond by raising their R\&D effort 
there ( $\ell^{\mathrm{n}}$ increases). We find that $\ell^{\mathrm{n}}$ increases more than $\ell^{\mathrm{s}}$ decreases, which represents one reason why migration increases utility and GNP growth rates. The second reason for the increase in growth rates is that $\mathrm{R} \& \mathrm{D}$ workers are more productive in the North (where $\lambda=1.28$ ) than in the South (where $\lambda=1.15$ ). For example, an Indian researcher would appear to contribute considerably more by working for a high-tech U.S. firm than by working for a low-tech Indian firm.

Even though growth rates increase in the North, it does not follow that Northern workers benefit from immigration. In fact, we find that discounted welfare for the typical worker in the North with no asset income (only wage income) drops from 1.42290 to 1.38456 due to the immigration quota. Northern workers benefit from the higher economic growth that immigration generates (real GNP growth increases from $0.51086 \%$ to $0.52613 \%$ ) but this is more than offset by the decrease in their wages (the Northern relative wage drops from 1.90808 to 1.78285$)$. The simulations show that growth considerations are dominated by wage considerations.

Given that workers lose from immigration, the question remains: do capital owners benefit from immigration quotas? Since immigration leads to higher R\&D effort in the North, the instantaneous probability that firms are driven out of business by further innovation rises. Also taking into account that immigration decreases world consumer expenditure, (6) implies that the stock market value of Northern firms unambiguously declines, which obviously hurts capital owners. Counterbalancing this, immigration lowers wages in the North, contributing to a decline in consumer prices and the cost of living for Northern capital owners. We find that the decline in stock market value is more significant and discounted welfare of the typical Northern capital owner decreases slightly from .22207 to .22177 due to immigration. However, this result is non-robust and hinges on our assumed benchmark parameter values. In several simulations with alternative parameter values, we find that Northern capital owners gain slightly from immigration (see footnote 8 , below). Our overall conclusion is that capital owners are not significantly affected (in either direction) by immigration quotas.

Besides the migrants themselves, we find that the only group that significantly benefits from immigration quotas are Southern workers. Discounted welfare for the typical Southern worker with no asset income (only wage income) increases from .74840 to .77980 due to the Northern immigration quota. The main reason why 
Southern workers benefit is simply that the prices of imported goods drop when other workers emigrate to the North. Southern workers also benefit from the faster rate of economic growth that emigration generates ( $\ell^{\mathrm{n}}$ increases).

Layard et.al. (1992) suggested the implementation of immigration quotas as part of a long run immigration policy to eliminate the incentives to migrate from Eastern to Western Europe. Figure 1 shows the utility effects of such a policy of mass migration into the Northern country and how it eventually eliminates any incentives for international migration. The vertical axis measures the (log) utility of workers in the North and in the South. Initially, at time $\mathrm{T}=1$, the utility level is much higher in the North than in the South but utility growth is identical in both countries. At time period $\mathrm{T}=2$, the Northern government allows immigration of a large number of workers from the South. This lowers the instantaneous utility level in the North and raises it in the South, and has the added effect of increasing the growth rate so that both countries' native populations enter a higher utility growth trajectory. At $\mathrm{T}=3$ there is another inflow of labor that again lowers the instantaneous utility level in the North and raises it in the South and is accompanied by a higher growth rate. At $\mathrm{T}=4$, the last immigrants arrive. Hereafter, Southern workers have no incentives to emigrate and the utility levels as well as the utility growth rates are equalized. ${ }^{8}$

One qualification of our results is worth stressing. We have assumed that workers in the South also benefit from the quality improvements of high-tech goods. If the assumption of identical preferences is dropped, and if, for instance, consumers in the South demand mainly low-tech goods, then our conclusion that the South benefits from

\footnotetext{
${ }^{8}$ To study the long run effects if the North pursues a sustained policy of increasing immigration, we have simulated gradual increases of worker immigration by assuming the following labor supply changes in five consequtive simulations: i) $\mathrm{L}^{\mathrm{n}}$ $=1.00$ and $\mathrm{L}^{\mathrm{s}}=2.00$, ii) $\mathrm{L}^{\mathrm{n}}=1.15$ and $\mathrm{L}^{\mathrm{s}}=1.85$, iii) $\mathrm{L}^{\mathrm{n}}=1.30$ and $\mathrm{L}^{\mathrm{s}}=1.70$, and $\left.\mathrm{iv}\right) \mathrm{L}^{\mathrm{n}}$ $=1.45$, and $\mathrm{L}^{\mathrm{s}}=1.55$. (The results are available upon request.) As immigration increases, the common utility growth rate continuously rises from $0.12 \%$ in the basic solution to $0.15 \%$ in the fourth simulation. Similarly, real GNP growth rises from $.51 \%$ to $.64 \%$. The discounted welfare of a Northern worker falls from 1.42 to 1.13 . For a rich Northern worker, discounted welfare falls from 1.64 to 1.35. At the same time, the discounted welfare of a Southern worker rises from 0.75 to 1.06 . The discounted welfare of Northern capital owners decreases if migration increases labor supply there from 1.15, but increases with further immigration. This shows that the qualitative effects on capital owner welfare are, in general, indeterminate.
} 
the emigration of its workers may be reversed.

\section{Effects of a Migration Tax.}

An important conclusion that we reached above is that Northern natives (both workers and capital owners) are hurt by immigration and that Southern workers (both natives and migrants) are the ones that benefit from immigration quotas in the North. Unless policy maker can rely on pure altruism in the North, an immigration quota policy could be politically infeasible if voters are well informed. We ask in this section if a migration tax can compensate Northern native workers enough so that they benefit from immigration. By a migration tax, we mean a tax on the wage income of immigrants, where the tax revenue generated is transferred to Northern native workers. Such a tax has no allocative effects but simply transfers expenditures from immigrants to natives.

The effects of a 20 percent migration tax on the .05 workers that migrate from the South to the North are presented in column 5. Not surprisingly, this migration tax lowers the incentives of Southern workers to migrate (from .48042 to .25763), and raises the discounted welfare of Northern native workers (from 1.38456 to 1.39858). But these native workers would have been even better off if no immigration had been allowed (discounted welfare of Northern native workers is 1.42290 in the benchmark case). Experiments with alternative tax rates and immigration quotas show that this result is robust: Migration taxes cannot alter the basic conclusion that immigration hurts the native population.

\section{Effects of Rich Worker Immigration.}

So far we have discussed the effects of poor worker immigration: workers that arrive in the North with nothing in their pockets and rely entirely on wage income for their financial support. What if the North only allows for immigration of rich workers, that is, workers with significant asset holdings? Are workers in the North likely to be more favorable to such an immigration policy?

The effects of a .05 immigration quota are presented in column 6 , where the .05 immigrants bring with them 25 percent of South's assets. Comparing columns 4 and 6 , we see that whether immigrants bring assets or not, post-immigration R\&D employment levels are the same in the two countries. Thus, both types of immigration generate the 
same utility and GNP growth rates. However, having rich instead of poor immigrants increases the Northern tax base, implying that Northern native workers are taxed less when wealthier individuals immigrate. The discounted welfare of Northern native workers is higher with rich worker immigration than with poor worker immigration and it follows that migration incentives are also higher with rich worker immigration quotas. Nevertheless, we still find that that native workers in the North are better off with no immigration than with rich worker immigration. Discounted welfare for a worker in the North drops from 1.42290 to 1.38463 due to rich worker immigration and for a rich native worker, discounted welfare drops from 1.64497 to 1.61169 .

\section{Effects of $R \& D S \mathbf{u} b$ sidies.}

The policy experiments that we have studied so far have all been related to immigration quotas. To study large quotas is natural since the incentives for migration are so strong, for instance, from Mexico and South America to the US, or from Eastern Europe and Northern Africa to the EU. Given that all the migration policies that we studied involve a political economy problem as the policies lower the discounted welfare of workers in the North (compared to the benchmark case), it is natural to proceed to study other policies. Though we expect only migration quotas to be able to substantially affect migration incentives, we can still ask if there are any policies that benefit the Northern workers and at the same time reduce migration incentives. In column 7 of Table 1, the steady-state effects of a 1 percent increase in the Northern R\&D subsidy (from $\mathrm{s}^{\mathrm{n}}=0.10$ to $\mathrm{s}^{\mathrm{n}}=0.11$ ) holding $\mathrm{s}^{\mathrm{s}}=0.10$ are reported. ${ }^{9}$ A higher Northern R\&D subsidy has the potential to lower migration incentives since Northern workers have to pay higher taxes to finance the subsidy increase and Southern workers get to "free ride" on the Northern government's growth promoting intervention.

We find that a higher Northern R\&D subsidy does indeed lead to faster economic growth in both countries (the utility growth rate increases from .01176 to .01186 ). Furthermore, the discounted welfare of a poor Northern worker rises from 1.42290 to

${ }^{9}$ It is natural to study R\&D subsidies in quality ladders models since the presence of R\&D externalities implies that the laissez-faire equilibrium is typically not optimal. See Grossman and Helpman (1991a). 
1.42554 and the discounted welfare of a rich Northern worker rises from 1.64497 to 1.64633. Thus, the Northern government can promote the welfare of both rich and poor workers by subsidising R\&D investments on the margin. However, the incentives for migration from the South to the North does not fall, but increases slightly (from .53941 to .54002). While Southern workers benefit from the faster growth that the higher Northern subsidy generates without incurring any increase in their taxes, they are also hurt by the increase in the relative wage w (from 1.90808 to 1.91298) which implies higher prices for goods imported from the North. In contrast, Northern workers benefit from the faster rate of economic growth and the higher Northern relative wage. The fact that they have to pay higher taxes to finance the R\&D subsidy increase turns out to be of secondary importance.

A higher Northern R\&D subsidy also lowers the rewards from winning an R\&D race since firms are driven out of business at a faster rate, implying that capital owners lose. By comparing discounted welfare of rich workers with that of capital owners, we see that if workers own the capital stock they will experience a net gain while if assets are separately owned, then the asset owners lose. For workers, the wage hike more than compensates for their loss in asset values.

We started this section by asking if a Northern R\&D subsidy would raise native workers' welfare and lower migration incentives. We found that welfare goes up but that migration incentives increased. Surprisingly, it is a Southern R\&D subsidy increase that has the desired effects. Although an R\&D subsidy in the North is more efficient in raising growth than a $R \& D$ subsidy in the South $\left(\lambda^{\mathrm{n}}=1.28\right.$ and $\left.\lambda^{\mathrm{s}}=1.15\right), \mathrm{R} \& D$ subsidies in the South have the added positive effect of limiting the international utility differences among workers and hence reducing migration incentives. The effects of a 1 percent increase in the Southern R\&D subsidy (from $\mathrm{s}^{\mathrm{s}}=0.10$ to $\mathrm{s}^{\mathrm{s}}=0.11$ holding $\mathrm{s}^{\mathrm{n}}=0.10$ ) are presented in the last column of Table 1.

\section{Robustness tests.}

Though we have evaluated immigration policies under what we believe are reasonable parameter values, we must ask to what extent our results hinge on the specific values assumed. We are particularly interested in possible cases where discounted welfare of 
Northern native workers increases as a result of immigration. The liberal immigration policies that we study would then be easy to justify.

We find that there are two cases in which migration benefits the native population. First, if the rate of discount is low enough, then the positive growth effect of immigration dominates the negative wage effect for Northern workers. But we find that the discount rate must be unreasonably low, below 1 percent, for immigration to generate a positive effect on the discounted welfare of the native workers in the North. Second, if there is a large enough difference in the rate of quality upgrading across the two countries, then immigration has a positive welfare effect on Northern natives. For instance, when we set $\lambda^{\mathrm{n}}=1.75$ and $\lambda^{\mathrm{s}}=1.10$, we find that immigration boosts the growth rate to such an extent that the higher growth more than compensates for the drop in Northern wage that immigration also generates. Table 2 shows the effects on a few selected variables. When the $\lambda$ 's differ a great deal, migration has only a small negative effect in the South but a large positive effect in the North.

Table 2. The $b$ enchmark and migration simulations when $\lambda^{\mathbf{n}}=\mathbf{1 . 7 5}$ and $\lambda^{\mathbf{s}}=\mathbf{1} .10$.

\begin{tabular}{|l|l|l|}
\hline Endogenous variables & $\begin{array}{l}\text { Benchmark } \\
\text { solution }\end{array}$ & $\begin{array}{l}\text { South to North } \\
\text { migration }\end{array}$ \\
\hline GNP growth rate & 1.74878 & 1.82839 \\
\hline Migration incentive & .47288 & .42097 \\
\hline $\begin{array}{l}\text { Disc. welfare of a } \\
\text { Northern worker }\end{array}$ & 2.17038 & 2.17548 \\
\hline $\begin{array}{l}\text { Disc. welfare of a rich } \\
\text { Northern worker }\end{array}$ & 2.52440 & 2.53622 \\
\hline
\end{tabular}

Such high $\lambda^{\mathrm{n}}$-values seem, however, problematic as they imply unreasonable allocations of labor to R\&D activities. In the benchmark simulation of Table 2, the North is allocating $76 \%$ of its labor force to R\&D! Thus, both cases of Northern native workers benefiting from immigration quotas appear to have limited empirical relevance.

We also reran all our policy experiments with high and low values of the remaining parameters and found that our qualitative results hold. Decreased population in the South, migration quotas, R\&D subsidies, migration taxes, and immigration of 
rich workers all have the same qualitative effects at these alternative parameter values. ${ }^{10}$

Finally, it is worth considering if our wage effects of immigration are of a reasonable magnitude. Altonji and Card (1991) find that a 1\% increase in a country's labor force due to immigration lowers wages by $1.2 \%$. Compared to our benchmark simulation, immigration that increases the labor force by $1 \%$ in the North (and lowers it in the South by $0.5 \%$ ) lowers the relative wage by $.86 \%$. (An exogenous increase in the Northern labor force by $1 \%$ lowers the Northern relative wage by $0.38 \%$. ) The wage effects of immigration in our simulations appear to be of roughly the right magnitude.

\section{Final Remarks}

We analyze the effects of immigration quotas on growth and discounted welfare using a North-South version of the quality ladders endogenous growth model. This model has attractive properties: Workers in the South have strong incentives to migrate to the North, and compared with the North, the South is characterized by low wages, labor abundance and production of low-tech goods.

We find that higher immigration quotas in the North increase the utility (and per capita GNP) growth rates of workers in both the North and the South. Immigration quotas also depress the real wages of workers in the North. Thus, in evaluating the overall effects of quotas on the discounted welfare of Northern workers, one must weigh the static utility losses from lower wages against the dynamic utility gains from higher per capita economic growth. If there is a sufficiently large difference between the $R \& D$ productivity of workers in the two countries, then the positive growth effects of immigration dominate and higher immigration quotas increase the discounted welfare of Northern workers. However, large R\&D productivity differences between the North and the South are associated with an unreasonably large Northern R\&D sector. We find that for plausble parameter values, the negative wage effects of immigration dominate and higher immigration quotas decrease the discounted welfare of Northern workers.

\footnotetext{
${ }^{10}$ As already noted, the effects on capital owners' discounted welfare depend on parameter values that we choose. The alternative parameter values were $b=.2$ or 1.9 , $\rho=.01$ or .10 and $\mathrm{L}^{\mathrm{n}}=.2$ or 1.75 .
} 
A standard result in static models of migration, as represented by for instance Berry and Soligo (1969), is that immigration benefits a representative agent in the host country. Interestingly, our dynamic model of migration yields the contrary result. The representative agent in our model is the rich worker in the North. We find that not only does immigration depress this worker's wage but the value of his assets also falls. ${ }^{11}$ Because immigration depresses the real wage of Northern workers, Northern firms respond by devoting more resources to $R \& D$ activities and innovations occur more frequently in each industry. This higher rate of market turnover in turn leads to lower expected discounted profits for innovative firms, or alternatively stated, a lower stock market value of firms. Thus, higher immigration quotas lower the discounted welfare of Northern capital owners in addition to lowering the discounted welfare of Northern workers. Our model suggests that the political economy problem associated with immigration policy is more severe than has previously been recognized. ${ }^{12}$

As we find that immigration in general lowers the discounted welfare of the native population in the North, we analyze alternative immigration policies that potentially could improve the situation of the native population. If we impose a tax on immigrants, and transfer the revenues to the natives, natives are still worse off compared to the nomigration case. Also if the immigration quota is restricted to apply only to rich immigrants, the native population still loses.

Therefore, our analysis suggests that the planned labor market integration between the present members of the EU and the candidate Eastern European countries will have a negative effect on the welfare of EU natives, workers as well as owners of firms. Although the technological differences between the US and Mexico are larger, the model suggests that they are not large enough to generate a positive welfare effect in the US from large scale Mexican immigration. Thus, to justify a policy involving large immigration quotas, one would have to assume altruism on the part of the immigration country. That altruism does play a role for immigration policy in developed countries is

\footnotetext{
${ }^{11}$ As previously noted, the result that capital owners lose from immigration does not always hold. The price level also falls as a result of immigration and sometimes the positive effect on asset owners' welfare of a lower price level may dominate.

${ }^{12}$ See Benhabib (1996).
} 
shown by the large share of refugees in recent migration flows to several West European countries.

In addition to these public policy conclusions, the model also has interesting implications for cross-country differences in economic growth rates. Because the countries are connected by trade in goods and any innovation benefits consumers in both countries, we find that structural or public policy differences between the two countries do not generate any differences in utility (or per capita GNP) growth rates. Public policy and/or structural differences generate differences in utility levels across countries but not differences in utility growth rates. The absence of growth differences simplifies our analysis because it implies that migration incentives are completely determined by international differences in worker utility levels (at any point in time).

It is of potential importance that we have assumed competitive wages. While this may be an acceptable assumption for the US, it is not necessarily a good assumption to make for the European Union where, in general, the wage is a bargaining outcome and labor markets are highly regulated. Regulated labor markets at fixed wages imply that employers cannot replace natives for immigrants at a wage rate below the prevailing one. Consequently, these economies experience immigration mainly in periods when there are many vacancies. While one therefore can expect less immigration in regulated labor markets, the influx of immigrants to such markets could still be expected to adversely affect native workers in the wage bargaining process with dynamic implications similar to those derived in this paper. 
REFERENCES

Altonji, J. and D. Card, (1991):"The Effects of Immigration on the Labor Market Outcomes of Less-skilled Natives", in Abowd and Freeman (eds.)Immigration, Trade and $t$ he Labor Market, National Bureau of Economic Research, University of Chicago Press.

Barro R. and X. Sala-i-Martin (1995):Economic Growth, McGraw-Hill, New York.

Benhabib, J. (1996):"On the Political Economy of Immigration," European Economic Review, 40, 1737-43.

Berry, R. A. and R. Soligo, (1969):"Some Welfare Aspects of International Migration," Journal of Political Economy, 77, 778-794.

Braun, J. (1993):"Essays on Growth and Migration," Ph.D. Dissertation, Harvard University.

Davidson, C. and P. Segerstrom (1998):"R\&D Subsidies and Economic Growth," mimeo, Michigan State University, (forthcoming in RAND Journal of Economics).

Denison, E. (1985): Trends in American Economic Growth, 1929-1982, (Washington, D.C.:The Brookings Institution).

Dixit, A. (1988):"A General Model of R\&D Competition and Policy", RAND Journal of Economics 19, 317-26.

Dolado,J. A. Goria and A. Ichino (1993):"Immigration and Growth in the Host Country," Paper presented at the Centre for Economic Policy Research Workshop on The Economics of International Migration: Econometric Evidence, Konstanz, Germany, February 26-27, 1993.

Grossman, G. and Helpman, E. (1991a):"Quality Ladders in the Theory of Growth," Review of Economic Studies, 58, 43-61,

Grossman, G.M. and Helpman, E. (1991b):Innovation and Growth in the Global Economy, the MIT Press, Cambridge, MA.

Layard, R., O. Blanchard, R. Dornbush and P. Krugman (1992):East-West Migration. The Alternatives, MIT Press, Cambridge, Mass.

Lundborg, P.(1997):"'The Free Movement of Labor Between Sweden and the New EU Members," in "A bigger and Better Europe? Final report from the committee on the economic effects of EU enlargement,"SOU 1997:156, Fritzes, Stockholm, Sweden.

Rivera-Batiz, F.L.(1994):"The Effects of Immigration on Economic Growth," Columbia University Working Paper, 
Rivera-Batiz, L. and Romer, P.M.(1991a):"Economic Integration and Endogenous Growth", Quarterly Journal of Economics, 106, 531-555,

Rivera-Batiz, L. and Romer, P.M. (1991b):"International Trade with Endogenous Technological Change," European Economic Review, 35, 971-1004,

Romer, P.(1990):"Endogenous Technological Change," Journal of Political Economy, 98, S71-S102.

Scherer, F. (1980):Industrial Market Structure and Economic Performance, HoughtonMifflin, Boston,

Segerstrom, P., Anant, T.C. and Dinopoulos, E. (1990):"A Schumpeterian Model of the Product Life Cycle," American Economic Review, 80, 1077-1091. 
Table 1 The results of $t$ he $b$ enchmark solution and the policy experiments. Benchmark parameter values $a$ re: $\lambda^{\mathbf{n}}=1.28, \lambda^{\mathbf{s}}=1.15, \rho=05, \alpha=5, \mathbf{L}^{\mathbf{n}}=1, L^{\mathbf{s}}=\mathbf{2}, b=1, \mathbf{s}^{\mathbf{n}}=\mathbf{s}^{\mathbf{s}}=\mathbf{0 . 1}, a=4.75$ and $\phi=9$

\begin{tabular}{|c|c|c|c|c|c|c|c|}
\hline $\begin{array}{l}\text { Endogenous } \\
\text { variables }\end{array}$ & $\begin{array}{l}\text { Bench- } \\
\text { mark } \\
\text { solution }\end{array}$ & $\begin{array}{l}\text { Lower } \\
\text { labor } \\
\text { force } \\
\text { in the } \\
\text { South }\end{array}$ & $\begin{array}{l}\text { South to } \\
\text { North } \\
\text { migra- } \\
\text { tion }\end{array}$ & $\begin{array}{l}\text { Taxed } \\
\text { South to } \\
\text { North } \\
\text { migra- } \\
\text { tion }\end{array}$ & $\begin{array}{l}\text { Rich } \\
\text { worker } \\
\text { migra- } \\
\text { tion }\end{array}$ & $\begin{array}{l}\text { R\&D } \\
\text { subsidy } \\
\text { in the } \\
\text { North }\end{array}$ & $\begin{array}{l}\text { R\&D } \\
\text { subsidy } \\
\text { in the } \\
\text { South }\end{array}$ \\
\hline $\begin{array}{l}\text { Northern R\&D } \\
\text { employment, } \ell^{\mathrm{n}}\end{array}$ & .28265 & .28265 & .30551 & .30551 & .30551 & .28705 & .28265 \\
\hline $\begin{array}{l}\text { Southern R\&D } \\
\text { employment, } \ell^{\mathrm{s}}\end{array}$ & .35274 & .33904 & .33904 & .33904 & .33904 & .35274 & .35834 \\
\hline Utility growth rate & .01176 & .01159 & .01211 & .01211 & .01211 & .01186 & .01183 \\
\hline GNP growth rate & .51086 & .50326 & .52613 & .52613 & .52613 & .51528 & .51396 \\
\hline $\begin{array}{l}\text { Northern } \\
\text { expenditures, } \mathrm{E}^{\mathrm{n}}\end{array}$ & 2.17890 & 2.12951 & 2.13033 & 2.13032 & 2.13826 & 2.17907 & 2.17467 \\
\hline $\begin{array}{l}\text { Southern } \\
\text { expenditures, } \mathrm{E}^{\mathrm{s}}\end{array}$ & 2.01545 & 1.96559 & 1.96478 & 1.96478 & 1.95684 & 2.01528 & 2.01323 \\
\hline $\begin{array}{l}\text { Northern relative } \\
\text { wage, w }\end{array}$ & 1.90808 & 1.86293 & 1.78285 & 1.78285 & 1.78285 & 1.91298 & 1.90515 \\
\hline Migration incentive & .53941 & .51850 & .48042 & .25763 & .48049 & .54002 & .53872 \\
\hline $\begin{array}{l}\text { Disc. welfare of a } \\
\text { Northern worker }\end{array}$ & 1.42290 & 1.40107 & 1.38456 & 1.39858 & 1.38463 & 1.42554 & 1.42383 \\
\hline $\begin{array}{l}\text { Disc. welfare of a } \\
\text { Southern worker }\end{array}$ & .74840 & .75487 & .77980 & .77980 & .77977 & .74897 & .74928 \\
\hline $\begin{array}{l}\text { Disc. welfare of a } \\
\text { rich Northern worker }\end{array}$ & 1.64497 & 1.62136 & 1.60545 & 1.61947 & 1.61169 & 1.64633 & 1.64539 \\
\hline $\begin{array}{l}\text { Disc. welfare of a } \\
\text { Northern asset owner }\end{array}$ & .22207 & .22029 & .22177 & .22177 & .22795 & .22079 & .22156 \\
\hline $\begin{array}{l}\text { Disc. welfare of a } \\
\text { Southern asset owner }\end{array}$ & .02476 & .02457 & .02474 & .24743 & .01856 & .02466 & .02468 \\
\hline
\end{tabular}


A PPENDIX. (A vailable on request.)

Effects of gradually eliminating the migration incentives from the South to $t$ he $N$ orth. Benchmark parameter values are: $\lambda^{\mathbf{n}}=\mathbf{1 . 2} 8, \lambda^{\mathbf{s}}=\mathbf{1 . 1 5}, \boldsymbol{\rho}=\mathbf{0 5}, \boldsymbol{\alpha}=\mathbf{5}, \mathbf{L}^{\mathbf{n}}=\mathbf{1}, \mathbf{L}^{\mathbf{s}}=\mathbf{2}, b=\mathbf{1}, \mathbf{s}^{\mathbf{n}}=\mathbf{s}^{\mathbf{s}}=\mathbf{0} .1, a=4.75$ and $\phi=9$.

\begin{tabular}{|l|l|l|l|l|}
\hline $\begin{array}{l}\text { Endogenous } \\
\text { variables }\end{array}$ & $\begin{array}{l}\text { Bench- } \\
\text { mark } \\
\text { solution }\end{array}$ & $\begin{array}{l}\text { Migra- } \\
\text { tion=.15 }\end{array}$ & $\begin{array}{l}\text { Migra- } \\
\text { tion=.30 }\end{array}$ & $\begin{array}{l}\text { Migra- } \\
\text { tion=.45 }\end{array}$ \\
\hline $\begin{array}{l}\text { Northern R\&D } \\
\text { employment, } \ell^{\mathrm{n}}\end{array}$ & .28265 & .351226 & .41980 & .48837 \\
\hline $\begin{array}{l}\text { Southern R\&D } \\
\text { employment, } \ell^{\text {s }}\end{array}$ & .35274 & .31164 & .27055 & .22945 \\
\hline Utility growth rate & .01176 & .01280 & .01379 & .01473 \\
\hline GNP growth rate & .51086 & .55593 & .59883 & .63960 \\
\hline $\begin{array}{l}\text { Northern } \\
\text { expenditures, E }\end{array}$ & 2.17890 & 2.03287 & 1.88610 & 1.73880 \\
\hline $\begin{array}{l}\text { Southern } \\
\text { expenditures, } \mathrm{E}^{\mathrm{s}}\end{array}$ & 2.01545 & 1.86374 & 1.71277 & 1.56234 \\
\hline $\begin{array}{l}\text { Northern relative } \\
\text { wage, w }\end{array}$ & 1.90808 & 1.56212 & 1.28961 & 1.06940 \\
\hline Migration incentive & .53941 & .36712 & .20546 & .04923 \\
\hline $\begin{array}{l}\text { Disc. welfare of a } \\
\text { Northern worker }\end{array}$ & 1.42290 & 1.31301 & 1.21577 & 1.12736 \\
\hline $\begin{array}{l}\text { Disc. welfare of a } \\
\text { Southern worker }\end{array}$ & .74840 & .84481 & .94878 & 1.06223 \\
\hline $\begin{array}{l}\text { Disc. welfare of a } \\
\text { rich Northern worker }\end{array}$ & 1.64497 & 1.53214 & 1.43366 & 1.34563 \\
\hline $\begin{array}{l}\text { Disc. welfare of a } \\
\text { Northern asset owner }\end{array}$ & .22207 & .22179 & .22312 & .22589 \\
\hline $\begin{array}{l}\text { Disc. welfare of a } \\
\text { Southern asset owner }\end{array}$ & .02476 & .02477 & .02495 & .02529 \\
\hline
\end{tabular}

